УДК 371.134: 811.1/.2 + 81’24 (045)

Данилюк Сергій Семенович

доктор педагогічних наук, доцент, професор кафедри практики англійської мови

Навчально-наукового інституту іноземних мов

Черкаський національний університет імені Богдана Хмельницького, м. Черкаси, Україна

sedan@bigmir.net

\title{
ВИКОРИСТАННЯ СИСТЕМИ ВПРАВ У ПРОЦЕСІ ФОРМУВАННЯ ПРОФЕСІЙНОЇ КОМПЕТЕНТНОСТІ МАЙБУТНІХ ФАХІВЦІВ ЗАСОБАМИ ІНТЕРНЕТ-ТЕХНОЛОГІЙ
}

\begin{abstract}
Анотація. У статті запропоновано систему вправ із використанням інтернет-технологій 3 урахуванням таких критеріїв, як «специфіка сприйняття інформації в Інтернеті» й «домінантна роль формованої компетенції» у процесі формування професійної компетентності майбутніх фахівців. Так, зокрема, за критерієм «специфіка сприйняття інформації в Інтернеті» виокремлюють вправи, спрямовані на: сприйняття електронного тексту (тобто швидкочитання); структуроване сприйняття інформації; антиципацію (здогадування, передбачення) змісту інформації. У свою чергу, за критерієм «домінантна роль формованої компетенції» виокремлюють вправи, спрямовані на формування: мовленнєвої компетенції (критичне читання й аудіювання); компенсаторної компетенції (вправи на розвиток здатності й готовності долати дефіцит іншомовних знань, наприклад, під час читання й аудіювання); навчально-пізнавальної компетенції (уміння користуватися довідковою літературою, різними словниками, інтернет-ресурсами).
\end{abstract}

Ключові слова: система вправ; професійна компетентність; інтернет-технології.

\section{1. ВСТУП}

Постановка проблеми. Складний процес формування професійної компетентності майбутніх фахівців засобами інтернет-технологій передбачає поступове й систематичне оволодіння ними лінгвістичними знаннями, формування мовних навичок до рівня автоматизму, розвиток мовленнєвих умінь, набуття великого персонального комунікативного досвіду, формування особистісних якостей майбутніх фахівців як активних суб'єктів навчальної діяльності, котрі саморозвиваються. Домогтися достатньо високого рівня лінгвістичної грамотності, яка $\epsilon$ важливою умовою повноцінного формування професійної компетентності майбутніх фахівців, в умовах відсутності іншомовного середовища досить складно і для студентів, i для викладача.

Аналіз останніх досліджень і публікацій. Проведений аналіз наукової літератури свідчить про те, що у вітчизняній педагогіці практично відсутні дослідження, у яких розкрито потенційні можливості використання ІКТ як засобу формування професійної компетентності фахівця. Безперечну цінність для визначення сутності і змісту IКТкомпетентності становлять роботи вітчизняних (Г. М. Алєксєєвої, Л. П. Буркот, Г. А. Дегтярьової, О.В. Тутової та ін.) і зарубіжних (В. А. Адольфа, О. Б. Зайцевої, I. Ф. Ісаєва, І. В. Склярової та ін.) дослідників. Аналіз теоретичних досліджень i практичного досвіду сучасної педагогічної діяльності показує, що, зважаючи на пильну увагу до підвищення якості професійної підготовки студентів, проблема використання IКТ як засобу формування професійної компетентності фахівців залишається недостатньо вивченою.

Сутність процесу інформатизації, який набув значного поширення в царині освіти i значною мірою впливає на динаміку розвитку сучасного суспільства, розкрито в роботах як вітчизняних (Р. С. Гуревич, К. І. Делегей, Н.В.Жаркова, І. Г. Сосюк й ін.), так і зарубіжних учених (Д. Белл, А. А. Вербицький, Т. П. Вороніна, К. К. Колін, А. Тоффлер й 
ін.). Водночас дидактичний потенціал інтернет-технологій висвітлено в низці дисертацій вітчизняних (В. М. Андрієвська, А. М. Коломієць, К. Р. Колос, О. В. Суховірський та ін.) i зарубіжних (Н. І. Аршинова, М. Б. Бетуганова, Ю. М. Верьовкіна-Рахальська, А. Д. Гарцов й ін.) дослідників.

Важливим засобом формування професійної компетентності майбутніх фахівців засобами інтернет-технологій $є$ різноманітні вправи, котрі I. О. Зимня розглядає як «багаторазове виконання певних дій, або видів діяльності, яке має за мету опанування ними, котре спирається на розуміння цієї мети та спільної програми дій і супроводжується свідомим контролем і коригуванням» [3, с. 108]. Таке визначення повністю відповідає загальнодидактичному тлумаченню терміну «вправа», котре знайшло синонімічне розуміння в роботах І. П. Підласого, П. І. Підкасистого, І. Ф. Харламова, Ю. І. Пассова, С. Ф. Шатілова, С. К. Фоломкіної та ін.

Мета статті полягає в побудові системи вправ із використанням інтернеттехнологій із метою професійної підготовки майбутніх фахівців у системі вищої професійної освіти.

\section{2. РЕЗУЛЬТАТИ ДОСЛІДЖЕННЯ}

Актуальність проблеми створення системи вправ, яка відповідає конкретним цілям і умовам формування професійної компетентності майбутніх фахівців, полягає ще й у тому, що практична методика не має у своєму розпорядженні універсальної системи вправ. Успіх навчання може гарантуватися лише раціональною, методично виправданою системою вправ, яка є релевантною у кожному конкретному випадку. Тому вважаємо визначення системи вправ, запропоноване С. Ф. Шатіловим, методично найточнішим. Під системою вправ він розуміє «сукупність необхідних типів, видів і різновидів вправ, виконуваних у такій послідовності й у такій кількості, котрі враховують закономірності формування навичок і вмінь у різних видах мовленнєвої діяльності в їх взаємодії і забезпечують максимально високий рівень оволодіння іноземною мовою в заданих умовах» [7, с. 223].

Якщо взяти до уваги той факт, що «система вправ у своїй тенденції $є$ аналогом мовленнєвої діяльності» [4, с. 104], повним аспектним розмаїттям якої належить опанувати майбутнім фахівцям, то уможливлюється таке формулювання основних поетапних завдань вправ, котрі утворюють систему [2, с. 108]:

1) отримання певного обсягу знань, формування навичок і вмінь;

2) забезпечення глибшого розуміння виучуваного матеріалу;

3) розвиток здатності використання вивченого матеріалу у практиці природного застосування;

4) розвиток творчих здібностей, особистісних якостей;

5) формування певних цінностей, здібностей здійснювати професійну діяльність.

Діяльнісна сутність вправи розглядається як [2, с. 107]:

а) структурна одиниця методичної організації навчального матеріалу (засіб навчання);

б) одиниця навчання.

Для створення системи вправ із формування професійної компетенції майбутніх фахівців засобами інтернет-технологій 3 урахуванням специфіки використання комплексного навчально-методичного матеріалу необхідно виходити з цілей і завдань навчання. Саме тому основні ознаки добору вправ мають певною мірою відображати ті завдання, які ми реалізуємо. 
Щодо створення системи вправ для формування професійної компетентності майбутніх фахівців, то такі вправи класифікуються за такими критеріями, як специфіка сприйняття інформації в Інтернеті й домінантна роль формованої компетентності.

Слід зазначити, що за критерієм «специфіка сприйняття інформації в Інтернеті» виокремлюють вправи, спрямовані на:

а) сприйняття електронного тексту (тобто швидкочитання);

б) структуроване сприйняття інформації;

в) антиципацію (здогадування, передбачення) змісту інформації.

Розглянемо докладніше зазначену типологію вправ.

\section{$\checkmark$ Вправи, спрямовані на формування умінь сприйняття інформації з екрана.}

Враховуючи специфіку комплексного навчально-методичного матеріалу, зокрема, роботу майбутніх фахівців з інформацією особливо під час пошукового й переглядового видів читання безпосередньо в мережі, виникає необхідність навчати студентів читання інформації з екрана, тобто вмінням швидкого читання.

М. I. Четверніна [6, с.96] у своєму дослідженні зазначає, що швидке читання характеризується такими особливостями:

а) переважно зорове сприйняття тексту;

б) сприйняття великого обсягу тексту за одиницю часу;

в) очі рухаються вертикально зверху вниз по центру сторінки;

г) швидке переключення уваги з одного смислового відрізка на інший;

г) стійкість і концентрація уваги при читанні;

д) залучення інформації, накопиченої читачем раніше;

е) активне використання екстралінгвістичної інформації (шрифтове i кольорове оформлення, символи й умовні позначення, пробіли і розташування рядків на екрані, а також схематична й ілюстративна наочність), яка допомагає охопити зміст тексту цілком.

Прискорення процесу читання уможливлюється в результаті скорочення тривалості фіксації очей і збільшення поля охоплення, усунення промовляння вголос i складового читання, а також регресій.

Для того щоб навчити майбутніх фахівців читати швидко, слід сформувати вміння, пов’ язані з розумінням й осмисленням змісту тексту. Ці вміння було розглянуто в роботах І. П. Толкачової [5] і А. О. Акішиної [1].

Так, І.П. Толкачова виокремлює такі вміння, які $\epsilon$ необхідними для функціонування переглядового виду читання [5, с. 14]:

а) визначити тему тексту;

б) виокремити смислові опорні пункти;

в) поділити текст на смислові фрагменти, виокремити смислові віхи / тези;

г) встановити зв'язок між смисловими віхами;

г) визначити головну думку тексту;

д) передбачити розвиток думки автора;

е) орієнтуватися у смисловому змісті тексту за словами-сигналами;

є) опускати маловажливу інформацію в результаті виокремлення головного й передбачення інформації, яка читається. вправи.

Для навчання навичок швидкого читання можна запропонувати подані нижче

1. Швидко перегляньте текст і зазначте слова та словосполучення, котрі стосуються теми .... .

2. Швидко перегляньте текст, після чого спробуйте переказати його зміст. 
3. Швидко прочитайте текст, запитання й відповіді до нього (час читання обмежується). Оберіть із кількох відповідей правильну (у відповідях на запитання наявні розбіжності в деталях).

4. Відновіть текст, визначаючи первісний порядок речень (час виконання обмежується).

\section{$\checkmark$ Вправи, спрямовані на формування вмінь структурованого сприйняття інформації.}

Як відомо, специфіка надання електронної інформації полягає у використанні гіпертекстової технології, коли інформація, наприклад, стаття в електронній газеті, на відміну від ії друкованого аналога, представлена не повністю, а міститься у вигляді заголовка $з$ невеликим абзацом, де у стислому вигляді представлено основну тему статті, а для того щоб ознайомитися зі статтею повністю, слід перейти за посиланням, наприклад, Read Article (More, Full Text). Крім посилання на текстову інформацію, тут може бути посилання й на графічну інформацію, аудіо- і відеофайли. У цьому випадку можна не лише прочитати інтернет-статтю, а й викликати аудіо- і відеосупровід інформації, яка зацікавила адресата.

Слід зазначити, що нині відсутне загальновизнане визначення терміна, котрий позначає таке сприйняття інформації у мережі. Технічні фахівці використовують у цьому контексті термін «розподілене сприйняття інформації», психологи, у свою чергу, дотримуються терміна «структуроване сприйняття інформації». У нашому дослідженні ми дотримуватимемося терміна, запропонованого психологами.

Для формування вмінь структурованого сприйняття інформації можна запропонувати подані нижче види завдань.

1. Зайдіть на інтернет-сайт газети (зазначається інтернет-адреса) i знайдіть усю інформацію (текстову, графічну, мультимедійну) з теми ... .

2. Перегляньте інтернет-сайт газети (зазначається інтернет-адреса й дата опублікування номера) й доберіть інформацію з теми .... .

3. Знайдіть на інтернет-сайті газети (зазначається інтернет-адреса й дата опублікування номера) основне інформаційне повідомлення. Скажіть, опис якої події міститься у ньому. Знайдіть у цьому номері іншу інформацію 3 цього питання.

Вправи, спрямовані на формування вмінь антиципації (передбачення) змісту інформації:

У процесі роботи 3 інформаційними ресурсами мережі Інтернет майбутнім фахівцям доводиться переглядати велику кількість інформації, причому як уже зазначалося, інформацію представлено в гіпертекстовому форматі, тому для того, щоб щоразу не переглядати весь матеріал під запропонованим гіперпосиланням, студентам часто доводиться прогнозувати зміст інформації за заголовком ы короткою анотацією основного змісту. У цьому аспекті слід формувати вміння антиципації, тобто вміння передбачати, прогнозувати зміст інформації.

Для формування умінь антиципації можна запропонувати такі завдання:

1. Зайдіть на інтернет-сайт газети (зазначається інтернет-адреса). Прочитайте заголовок статті й спробуйте припустити, про що йтиметься у статті. Перейдіть за гіперпосиланням і перевірте правильність / неправильність своїх припущень.

2. Зайдіть на інтернет-сайт газети (зазначається інтернет-адреса) i знайдіть, орієнтуючись лише за заголовками статей, усю інформацію з теми ... .

У свою чергу, за критерієм «домінантна роль формованої компетенції», виокремлюють вправи, спрямовані на формування:

а) мовленнєвої компетенції (критичне читання й аудіювання); 
б) компенсаторної компетенції (вправи на розвиток здатності й готовності долати дефіцит іншомовних знань, наприклад, у читанні й аудіюванні);

в) навчально-пізнавальної компетенції (уміння користуватися довідковою літературою, різними словниками, інтернет-ресурсами).

Розглянемо докладніше зазначену типологію вправ:

$\checkmark$ Вправи, спрямовані на формування мовленнсвої компетенції (критичне читання й аудіювання):

Для формування мовленнєвої компетенції засобами інтернет-технологій основний акцент робиться на формуванні й розвитку інтелектуальних умінь критичного мислення, зокрема, критичного читання й аудіювання.

I. Вправи, спрямовані на формування інтелектуальних умінь критичного читання.

Розвиток умінь критичного мислення носить еволюційний характер і відбувається поетапно, відповідаючи логіці пізнавальної діяльності. У цьому дослідженні під час розроблення комплексу вправ на розвиток інтелектуальних умінь критичного мислення ми дотримуємося таксономії Б. Блума [8, с. 104].

Згідно теорії Б. Блума існує шість рівнів пізнання (знання, розуміння, застосування, аналіз, синтез, оцінка), послідовний і цілеспрямований розвиток яких дозволяє досягти студентам найвищих результатів навчання.

У підгрунті всіх видів читання (вивчального, ознайомлювального, переглядового й пошукового) лежать основні вміння, якими читач користується у всіх ситуаціях. Вони пов'язані з розумінням змісту, його осмисленням й опрацюванням. Зазначимо, що в методиці в процесі навчання прийнято певну послідовність роботи над текстом передтекстові завдання, робота з текстом, текст і післятекстові завдання.

На початковому етапі, котрий відповідає рівню «знання» в таксономії Б. Блума, слід 3'ясувати початкові знання майбутніх фахівців щодо запропонованої теми обговорення, відображеної у тексті, що їм відомо про ту чи іншу подію, яке їх ставлення до неї. У цьому випадку рекомендується провести бесіду, метою якої $\epsilon$ ввести студентів в обговорювану ситуацію, зацікавити іiі проблематикою, тобто сформувати мотивацію до подальшої роботи над текстом. Це передтекстові завдання. На цьому етапі можна запропонувати загальні завдання, характерні для всіх видів читання:

1. Що Вам відомо про ... ?

2. Які асоціації у Вас викликає назва, подія ... ?

3. Як ви ставитеся до ...?

4. Яке значення Ви надаєте події, явищу ... ?

5. Що б Ви хотіли дізнатися додатково про подію, явище ... ?

Другий рівень таксономії Б. Блума «розуміння» передбачає різні рівні розуміння: вміти визначити головну думку в тексті, знайти підтверджувальну або уточнювальну інформацію, встановити деталі або окремі факти тексту, причинно-наслідкові зв'язки між ними, інтерпретувати прочитане, уміти виокремити загальний зміст тексту. Тут можна говорити про повне розуміння (вивчальне читання), розуміння основного змісту без деталей (ознайомлювальне читання), розуміння головної думки, основної теми (пошукове, переглядове читання).

Вивчальне читання передбачає максимально повне й точне розуміння всієї інформації, яка міститься в тексті, і іiі критичне осмислення. Це вдумливе й неспішне читання, котре передбачає цілеспрямований аналіз змісту прочитаного. Вивчальне читання вирізняється великою кількістю регресій, навмисним виокремленням найважливіших тез і неодноразовим промовлянням їх: уголос з метою кращого запам'ятовування змісту для подальшого переказу, обговорення, використання в роботі. 
Під час ознайомлювального читання майбутні фахівці мають отримати основну інформацію, яка міститься в тексті. Цей вид читання не вимагає спеціального вивчення, а лише вміння розрізняти головну і другорядну інформацію.

Переглядове читання передбачає отримання загального уявлення про інформацію, котра читається. Це побіжне, вибіркове читання, головна мета якого зрозуміти, чи становить інформація, яка міститься в тексті, інтерес для читача. Тому залежно від мети переглядового читання і ступеня повноти отримання інформації, І. П. Толкачова [5, с. 12] виокремлює чотири підвиди переглядового читання:

1) конспективне, використовуване для виокремлення основних думок; полягає у сприйнятті лише найзначущіших смислових одиниць тексту, шо складають логіко-фактологічний ланцюжок;

2) реферативне, під час якого читача цікавить лише найосновніше в змісті матеріалу, усі подробиці опускаються як несуттєві для розуміння головного;

3) оглядове, метою якого є визначення сутності повідомлення. Воно спрямоване на виокремлення головної думки тексту, причому переважно на грунті його структурно-смислової організації. Інтерпретація прочитаного обмежується винесенням найзагальнішої оцінки текстового матеріалу й визначенням відповідності тексту інтересам читача;

4) орієнтувальне, використовуване для встановлення наявності в тексті інформації, яка становить для читача інтерес або стосується певної проблеми.

Пошукове читання спрямоване на знаходження в тексті конкретної інформації. Таке читання, як і переглядове, припускає наявність уміння орієнтуватися в логікосмисловій структурі тексту і знаходити в ньому необхідну інформацію.

У виконанні післятектових завдань рекомендується варіювати фронтальні види робіт з роботою в парах або малих групах співробітництва (3-4 особи).

1. Прочитайте інтернет-статтю і дайте відповідь на запитання по іï змісту (більшою мірою характерне для вивчального й ознайомлювального видів читання).

2. Обговоріть, чи виражена головна думка в заголовку (вивчальне, ознайомлювальне читання).

3. Прочитайте текст і поясніть, наскільки заголовок відповідає змістові (більшою мірою характерне для вивчального й ознайомлювального читання).

Ці види завдань припускають фронтальні види роботи.

У малих групах співробітництва рекомендується виконувати подані нижчк види вправ.

1. Вправи, спрямовані на формування вміння виокремлювати головні думки (ці завдання можна віднести до будь-якого виду читання).

1. Прочитайте інтернет-статтю i зазначте, де сформульовано головну думку: у вступній частині, у заключній частині, у заголовку.

2. Оберіть із низки речень те, к якому міститься головна думка в тексті.

3. Визначте й обговоріть у групах, яка проблема актуалізується в тексті.

2. Вправи, спрямовані на формування вміння переструктурувати інформацію (ці завдання характерні для ознайомлювального читання в більшій мірі і для вивчального).

1. Поділіть текст на смислові частини і дайте назву кожній із них.

2. Поділіть текст на смислові частини й підкресліть речення, котре виражає головну думку кожної частини.

3. Складіть короткий виклад тексту (summary) в усному (писемному) вигляді. 
На етапі «застосування» студенти мають уміти застосовувати отримані знання, факти в обговоренні загальної проблеми, а також визначати, наскільки їм необхідна додаткова інформація (ці завдання характерні для всіх видів читання).

На цьому етапі можна запропонувати такі завдання.

1. Подумайте, де і як Ви можете використовувати отриману з тексту інформацію?

2. Перегляньте запропоновані Вам тексти й доберіть із них факти, котрі стосуються теми .... .

3. Доповніть інформацію, отриману 3 тексту. 3 цією метою перегляньте відповідні інформаційні сайти (посилання може дати викладач) і знайдіть інформацію з виучуваної теми ... .

Останні три рівні належать до продуктивного рівня і $\epsilon$ вищим рівнем інтелектуальних умінь.

На рівні «аналізу» майбутні фахівці мають уміти аналізувати структуру й логіку міркувань автора, уміти знаходити додаткову інформацію з різних джерел і зіставляти їі 3 наявною інформацією $з$ метою оцінки надійності, точності, об' єктивності думки автора, уміння визначити наявність упередження, помилкової аргументації або маніпуляції думкою читача. Слід також навчити студентів під час аналізу інформації брати до уваги історичний і культурний контекст і звертати увагу на те, як він може вплинути на інтерпретацію інформації. Інтелектуальні уміння цього рівня характерні для вивчального, ознайомлювального, а також переглядового й пошукового видів читання. На зазначеному рівні використовуються проблемні методи, котрі передбачають навчання у співробітництві.

Тут можна запропонувати подані нижче вправи.

1. Вправи, спрямовані на формування вміння аналізувати структуру цे логіку аргументації автора тексту.

1. Зазначте аргументи, які автор наводить на підтримку своєї точки зору. Обговоріть це у групах.

2. Зазначте спосіб аргументації: односторонній / двосторонній. У разі двосторонньої аргументації, випишіть аргументи «за» $\mathrm{i}$ «проти».

2. Вправи, спрямовані на формування вмінь аналізувати й порівнювати інформачію з різних джерел, оцінювати ї̈ надійність, точність, достовірність, а також уміння розпізнати думку й визначити ї об'єктивність:

1. Розділіться на групи й обговоріть, які положення відображають факти, а які думки, припущення, оцінку. Обгрунтуйте свої висновки.

2. Визначте, чи є в міркуваннях автора суб'єктивні судження, не підкріплені фактами. Проведіть інформаційний пошук для підтвердження своїх висновків.

3. Випишіть із тексту речення, у яких містяться певні думки. 3 якими 3 них Ви згодні, а з якими ні. Обгрунтуйте свою думку.

4. Знайдіть відмінності в основних положеннях декількох текстів на одну й ту саму тему. Поясніть причину розбіжностей.

5. Розділіться на групи по 3-4 особи й доведіть правильність / неправильність позиції автора з Вашої точки зору. Використовуйте додаткову інформацію з інших джерел.

3. Вправи, спрямовані на формування вміння виявляти упередженість суджень, помилкову аргументаџію або способи маніпуляиії.

1. Розділіться на групи й випишіть із тексту оцінні епітети, слова, котрі мають емоційне забарвлення. Яку роль вони відіграють? Чи впливають вони на Ваше сприйняття? 
2. Обговоріть у групах, якими є погляди автора на проблему ... ? Як вони проявляються у статті, у чому проявляється суб' єктивність підходу?

3. Розділіться на групи. Виокремте у статті суперечливий момент або положення, шо викликають у Вас незгоду або сумніви. Подумайте, чи потрібна Вам додаткова інформація. Знайдіть іiі.

На рівні «синтез» майбутні фахівці мають уміти узагальнити інформацію, встановити зв'язки між різними подіями чи явищами, структурувати інформацію, щоб використовувати iї для формулювання висновків, а також для прийняття рішення про необхідність використання тієї чи тієї додаткової інформації у розв’язанні певних проблем (інтелектуальні вміння на цьому рівні здебільшого характерні для вивчального й ознайомлювального читання). Виконання вправ для формування цих умінь передбачає роботу у співпраці з наступним спільним фронтальним обговоренням.

На цьому етапі можна запропонувати подані нижче вправи.

1. Вправи, спрямовані на формування вміння встановлювати причинно-наслідкові зв'язки ци використовувати отриману інформацію для формулювання аргументованих висновків.

1. Доведіть правильність / неправильність пропонованого автором розв'язку з Вашої точки зору (це завдання може бути виконане в усному або писемному вигляді).

2. Поясніть, як вплинула отримана інформація на Ваше ставлення до обговорюваного питання.

3. Обговоріть у групах і запропонуйте заходи / шляхи розв'язання питання ... після аналізу ситуації / інформації.

2. Вправи, спрямовані на формування вміння створювати на трунті проаналізованої інформації прогнози подальщого розвитку подій, щзо може потребувати додаткової інформації.

1. Порівняйте описувану ситуацію з нинішньою. Які відбулися зміни? 3 чим це пов'язано? Знайдіть додаткову інформацію, яка допоможе Вам відповісти на поставлене запитання.

2. Продумайте, які можуть бути наслідки прийнятого рішення. Обговоріть у групах і запропонуйте альтернативне рішення в разі несприятливого розвитку подій. Поясніть, що вплинуло на прийняття цього рішення.

3. Вправи, спрямовані на формування вміння розрізняти й зіставляти різні точки зору, що висловлюються у прочесі опрацювання інформації.

1. Обговоріть ... у групах. Вислухавши / вивчивши аргументацію опонентів, які контраргументи Ви можете уявити?

4. Вправи, спрямовані на формування вміння прийняти або відкинути думки, котрі висловлюються у процесі роботи з інформацією.

1. Після проведення інформаційного пошуку зберіться у групі, порівняйте й обговоріть отримані дані. Чи достатньо отриманої інформації для продовження роботи над проблемою?

Метою вправ на рівні таксономії Б. Блума «оцінка» $є$ формування таких умінь:

а) оцінити інформацію з розглянутої проблеми;

б) визначити, наскільки знайдена інформація спростовує або підтверджує інформацію, отриману з інших джерел;

в) зробити аргументовані висновки на грунті зібраної інформації і наявних знань.

На цьому рівні можна запропонувати подані нижче вправи.

1. Висловіть своє ставлення до прочитаної інформації. Скажіть, чи згодні Ви 3 оцінкою автором подій, фактів. 
2. Оцініть, наскільки знайдена Вами інформація відповідає розглянутій проблемі.

3. Зробіть висновки з проблеми ... .

4. Поясніть, у чому Ви бачите розбіжності в підході автора цього тексту й додаткової інформації з теми ... .

5. Напишіть есе на тему ... .

II. Вправи, спрямовані на формування вмінь аудіювання.

Навчання аудіюванню автентичних повідомлень мережі Інтернет включає три етапи:

1) виконання завдань перед прослуховуванням;

2) аудіювання;

3) виконання завдань після аудіювання тексту.

На попередньому етапі використовуються подані нижче види роботи.

1. Прослухайте аудіозапис двічі i спробуйте здогадатися про значення незнайомих слів і словосполучень, якщо такі Вам трапляться.

2. Що Ви знаєте про ... ?

3. Прочитайте запропоновані заголовки аудіотекстів i спробуйте визначити за ключовими словами, про що йтиметься.

Етап аудіювання включає прослуховування аудіозапису двічі.

На етапі після прослуховування тексту відбувається контроль розуміння прослуханого матеріалу. На цьому етапі можна запропонувати подані нижче вправи.

1. Заповніть запропоновану таблицю, зазначаючи основні моменти за змістом аудіотексту (студентам необхідно вказати основний зміст інформації у вигляді відповіді на питання: «Хто?», «Що?», «Де?», «Коли?» тощо, що полегшує розуміння змісту інформації).

2. Зазначте правильні / неправильні твердження (true / false statements), використовуючи інформацію із заповненої таблиці.

3. Виберіть правильний варіант відповіді із запропонованих питань за змістом тексту (multiple choice).

4. Відповідайте на запитання за змістом аудіотексту.

5. Підготуйте резюме за прослуханим аудіозаписом.

$\checkmark$ Вправи, спрямовані на формування компенсаторної компетенції.

Компенсаторна компетенція припускає розвиток здатності людини долати дефіцит своїх іншомовних знань, навичок і вмінь, яка виявляє себе у вмінні:

a) у разі незнання якого-небудь потрібного слова замінити його синонімом або описом поняття;

б) не «зациклюватися» на незнайомому, наприклад, якщо щось незрозуміло під час аудіювання або читання, щоб із контексту зрозуміти думку автора.

У цьому випадку рекомендуються подані нижче вправи.

1. Вправи на розуміння текстів, які містять незнайомі слова, котрі не впливають на розуміння загального змісту при читанні:

1. Прочитайте абзац і спробуйте зрозуміти його, не звертаючи уваги на незнайомі слова.

2. Прочитайте фрагмент тексту і спробуйте 3 контексту здогадатися про значення слів, які перешкоджають розумінню основного змісту тексту.

3. Прочитайте текст і спробуйте зрозуміти його без словника.

2. Вправи на навчання сприйняттю аудіотекстів, які містять незнайомі слова, котрі не впливають на розуміння загального змісту. 
1. Прослухайте аудіотекст і заповніть запропоновану таблицю за основним змістом. У разі розуміння основної інформації усі елементи таблиці виявляться заповненими.

2. Прослухайте аудіотекст і викладіть його зміст.

$\checkmark$ Вправи, спрямовані на формування навчально-пізнавальної компетенції (уміння користуватися довідковою літературою, різними словниками, у першу чергу, інтернет-ресурсами).

Навчально-пізнавальна компетенція припускає розвиток загальних і спеціальних навчальних умінь, які дозволяють удосконалювати навчальну діяльність 3 оволодіння іноземною мовою, задовольняти за іiї допомогою пізнавальні інтереси в інших галузях знання. Навчально-пізнавальні вміння пов'язані з прийомами самостійного здобуття знань, а саме:

а) використовувати різні словники й довідкову літературу;

б) аналізувати, узагальнювати інформацію;

в) виокремлювати потрібну (основну) інформацію з різних джерел, у тому числі інтернет-ресурсів.

Слід зазначити, що в роботі з інтернет-ресурсами майбутні фахівці мають уміти користуватися так званими віртуальними словниками й енциклопедіями, що набагато зручніше, ніж, наприклад, традиційними друкованими виданнями. В Інтернеті існують спеціальні сайти, де представлені різноманітні електронні словники, довідники, енциклопедії.

Можна запропонувати подані нижче завдання на формування вмінь навчальнопізнавальної компетенції.

1. Знайдіть інформацію 3 теми ... на інформаційних сайтах (можна дати посилання або надати право вибору студентам).

2. Порівняйте і проаналізуйте висвітлення інформації поз теми ... на різних інформаційних сайтах (можна дати посилання).

3. Яким словником (довідником) Вам необхідно скористатися, щоб пояснити значення таких реалій ... ?

Порівняйте тлумачення таких понять ... у словнику Вебстера (http://www.mw.com) й у Британській енциклопедії (http://www.britannica.com).

\section{3. ВИСНОВКИ ТА ПЕРСПЕКТИВИ ПОДАЛЬШИХ ДОСЛІДЖЕНЬ}

Запропоновані типи завдань можуть бути представлені як у чистому, так й у змішаному з іншими завданнями варіанті. Творче використання логічно опрацьованого матеріалу 3 певної теми 3 різних інформаційних джерел у різноманітних варіантах презентації (друкований текст, електронна версія, усний виклад (доповідь, промова, виступ), відеоролик, інсценування тощо) припускає фактичне знання матеріалу й ретельну підготовку як викладача, так і майбутніх фахівців.

Перспективи подальших пошуків у напрямку дослідження вбачаємо в необхідності проаналізувати психологічні, педагогічні й лінгвістичні засади формування професійної компетентності сучасних фахівців засобами інтернеттехнологій.

\section{СПИСОК ВИКОРИСТАНИХ ДЖЕРЕЛ}

1. Акишина А. А. Учим читать быстро и эффективно: путь к педагогическому мастерству / А. А. Акишина, В. И. Шляхов. - М. : Русский язык, 1991. - 134 с. 
2. Аршинова Н. И. Формирование иноязычной лингвистической компетенции студентов вуза с применением средств компьютерных технологий : дис. ... канд. пед. наук : 13.00 .08 / Аршинова Наталья Ивановна. - Петрозаводск, 2007. - 189 с.

3. Зимняя И. А. Психологические аспекты обучения говорению на иностранном языке / И. А. Зимняя. - М. : Просвещение, 1985. - 160 с.

4. Львова С. А. Обучение профессионально-ориентированному иноязычному общению студентов факультета управления (немецкий язык) : дис. ... канд. пед. наук : 13.00.02 / Львова Светлана Анатольевна. - С.-Пб., 2006. - 223 с.

5. Толкачёва И. П. Методика обучения чтению газет на английском языке. (К проблеме скоростного чтения) : автореф. дис. ... канд. пед. наук : 13.00.02 / И. П.Толкачёва. — M, 1979. — 24 с.

6. Четвернина М. И. Методика обучения учащихся старших классов созданию вторичных иноязычных текстов на материале аутентичной информации Интернета (на материале английского языка) : дис. ... канд. пед. наук : 13.00.02 / Четвернина Маргарита Ивановна. — М., 2003. — 209 с.

7. Шатилов С. Ф. Методика обучения немецкому языку в средней школе / С. Ф. Шатилов. - М. : Просвещение, 1986. - 223 с.

8. Bloom B. S. Taxonomy of Educational Objectives: The Classification of Educational Goals / B. S. Bloom [et al.]. — New York : Addison Wesley Publishing Company, 1984. — Handbook 1: Cognitive Domain. - 207 p.

Матеріал надійшов до редакиії 20.09.2014 p.

\title{
ИСПОЛЬЗОВАНИЕ СИСТЕМЫ УПРАЖНЕНИЙ В ПРОЦЕССЕ ФОРМИРОВАНИЯ ПРОФЕССИОНАЛЬНОЙ КОМПЕТЕНТНОСТИ БУДУЩИХ СПЕЦИАЛИСТОВ СРЕДСТВАМИ ИНТЕРНЕТ-ТЕХНОЛОГИЙ
}

\author{
Данилюк Сергей Семенович \\ доктор педагогических наук, доцент, профессор кафедры практики английского языка \\ Учебно-научного института иностранных языков \\ Черкасский национальный университет имени Богдана Хмельницкого, г. Черкассы, Украина \\ sedan@bigmir.net
}

\begin{abstract}
Аннотация. В статье предложена система упражнений с использованием интернеттехнологий с учетом таких критериев, как «специфика восприятия информации в Интернете» и «доминантная роль формируемой компетенции» в процессе формирования профессиональной компетентности будущих специалистов. Так, в частности, по критерию «специфика восприятия информации в Интернете» выделяют упражнения, направленные на: восприятие электронного текста (т. е. скорочтения); структурированное восприятие информации; антиципации (домыслы, предвидение) содержания информации. В свою очередь, по критерию «доминантная роль формируемой компетенции», выделяют упражнения, направленные на формирование: речевой компетенции (критическое чтение и аудирование); компенсаторной компетенции (упражнения на развитие способности и готовности преодолевать дефицит иностранных знаний, например, при чтении и аудировании); учебно-познавательной компетенции (умение пользоваться справочной литературой, различными словарями, интернет-ресурсами).
\end{abstract}

Ключевые слова: система упражнений; профессиональная компетентность; интернет-технологии.

\section{USAGE OF EXERCISES IN THE PROCESS OF FORMATION OF FUTURE SPECIALISTS' PROFESSIONAL COMPETENCE BY MEANS OF INTERNET TECHNOLOGIES}

\author{
Serhiy S. Danylyuk \\ Doctor in Pedagogical Sciences, Associate Professor, Professor of Conversational English Department, \\ Educational-Scientific Institute of Foreign Languages \\ Bohdan Khmelnytsky National University at Cherkasy, Cherkasy, Ukraine \\ sedan@bigmir.net
}




\begin{abstract}
The system of exercises which require usage of Internet technologies, taking into account such criteria as "specificity of perception of information on the Internet" and "predominant role of the formed competence" in the formation of future specialists' professional competence is offered in the paper. Thus, in particular, according to the criterion of "the perception of information on the Internet" exercises are singled out, which are aimed at: the perception of the electronic text (i.e., speed reading); structured information perception; anticipation of content of information. In their turn, according to the criterion of "the dominant role of the formed competence" exercises are singled out which are aimed at establishing: speech competence (critical reading and listening); compensatory competence (exercises aimed at developing the ability and willingness to overcome the shortage of foreign knowledge, such as reading and listening); educational-and-cognitive competence (ability to use reference books, various dictionaries, the Internet resources).
\end{abstract}

Key words: system of exercises; professional competence; Internet technologies.

\title{
REFERENCES (TRANSLATED AND TRANSLITERATED)
}

1. Akishina A. A. We Teach to Read Quickly and Effectively: A Way to Pedagogical Skills / A. A. Akishina, V. I. Shlyakhov. - M. : Russkij yazyk, 1991. - 134 p. (in Russian).

2. Arshinova N. I. Formation of Foreign Language Linguistic Competence of Higher Educational Establishments Students by Means of Computer Technologies : dis. ... cand. ped. sciences : 13.00.08/ Arshinova Natalya Ivanovna. — Petrozavodsk, 2007. — 189 p. (in Russian).

3. Zimnyaya I. A. Psychological Aspects of Teaching Speaking in a Foreign Language / I. A. Zimnyaya. M. : Prosveshcheniye, 1985. - 160 p. (in Russian).

4. L'vova S. A. Teaching Professionally Oriented Foreign Language to Students of Management Department (The German Language) : dis. ... cand. ped. sciences : 13.00.02 / L'vova Svetlana Anatolyevna. - S.-Pb., 2006. - 223 p. (in Russian).

5. Tolkachyova I. P. Methods of Teaching Reading Newspapers in English. (To the Problem of Quick Reading) : abstract of dis. ... cand. ped. sciences : 13.00.02 / Irina PetrovnaTolkachyova. — M, 1979. 24 p. (in Russian).

6. Chetvernina M. I. Methods of Teaching Pupils of Senior Forms to Create Secondary Foreign Language Texts on the Material of Authentic Internet Information (a Study of English) : dis. ... cand. ped. sciences : 13.00.02 / Chetvernina Margarita Ivanovna. — M., 2003. — 209 p. (in Russian).

7. Shatilov S. F. Methods of Teaching German in Secondary School / S. F. Shatilov. - M. : Prosveshcheniye, 1986. - 223 p. (in Russian).

8. Bloom B.S. Taxonomy of Educational Objectives: The Classification of Educational Goals / B. S. Bloom [et al.]. — New York : Addison Wesley Publishing Company, 1984. — Handbook 1: Cognitive Domain. — 207 p. (in English). 